\title{
In vitro tissue culture initiation from potted and garden Hydrangea macrophylla explants
}

\author{
Metka ŠIŠKO \\ University of Maribor, Faculty of Agriculture and Life Sciences, Pivola 10, 2311 Hoče, Slovenia
}

\begin{abstract}
The effect of sterilisation treatments on the initiation of the culture of three Hydrangea macrophylla genotypes in vitro was studied. The results indicated difference among different disinfection treatment; the consequence of treatments with dichloroisocyanuric acid, in combination with silver nitrate, was a significantly higher survival rate comparing to treatments based on $\mathrm{NaOCl}$. Success of sterilisation was significantly influenced by studied genotypes. Two potted hydrangea genotypes (G2 and G3) showed higher survival rate ( $45.00 \%, 55.00 \%$, respectively) comparing to the genotype 1 (originated from a local garden), which exhibited the highest percentage of contamination rate $(58.75 \%)$. Culturing the explants on a McCown woody plant medium supplemented with BAP at $2 \mathrm{mg} / \mathrm{L}$ and NAA at $0.005 \mathrm{mg} / \mathrm{L}$ produced the highest number of shoots with multiplication rate of 1.31 in 5 weeks. The highest rooting percentage (100.00 \%) was obtained with the genotype 2 on a McCown woody plant medium supplemented with $0.5 \mathrm{mg} / \mathrm{L}$ IBA.
\end{abstract}

Key words: micropropagation, tissue culture, hydrangea, Hydrangea macrophylla, plant disinfection

\section{INTRODUCTION}

Hydrangeas (Hydrangea macrophylla (Thunb.) Ser., Hydrangeaceae) are potted florists plants or garden plants growing as deciduous shrubs, and are up to $2 \mathrm{~m}$ tall and approximately $2.5 \mathrm{~m}$ wide. The term 'macrophylla' means large or long leaves (the leaves can grow to $15 \mathrm{~cm}$ in length) (Harrison 2012). The inflorescence of $H$. macrophylla is a corymb with all individual flowers placed in a plane or hemisphere, or even a whole sphere in some cultivated forms. Blooms can be blue, red, pink, light purple, or dark purple. The colour is affected by soil pH. An acid soil (pH below 7) will usually induce blue floral colour, whereas in alkaline soil ( $\mathrm{pH}$ above 7) flowers will be more pinkish. The colour change is associated with the presence of aluminium ions.

There are a few reports on the micropropagation of hydrangeas. Sebastian and Heuser (1987) established in vitro propagation of $H$. quercifolia through differentiation of leaf callus into plantlets and stimulation of axillary bud released from the dormant buds. The plantlets obtained from leaf callus were suitable for commercial propagation. Abou Dahab (2006) successfully conducted experiments aimed at developing an in vitro propagation protocol for $H$. macrophylla plants. Ruffoni et al. (2013) placed Hydrangea spp. explants on MS medium supplemented with benzyl adenine (BA) $(0.25 \mathrm{mg} / \mathrm{L})$ and sucrose $(30 \mathrm{~g} / \mathrm{L})$. The rooting of proliferated shoots was $100 \%$ on a medium containing naphthalene acetic acid (NAA) $(0.5 \mathrm{mg} / \mathrm{L})$. The main aim of this experiment was to study the effect of some disinfection treatments on the survival rate of $H$. macrophylla explants cultured in vitro.

\section{MATERIALS AND METHODS}

\section{Plant material and establishment of in vitro culture}

The plant material was obtained during April from vigorous one year old shoots of $H$. macrophylla plant growing in a local garden (G1), and from potted H. macrophylla plants (G2 and G3). The plant material was cut into $1 \mathrm{~cm}$ single node explants.

Four sterilisation treatments were evaluated for the disinfection of the plant material: (a) the explants were dipped

${ }^{*}$ Correspondence to:

E-mail:metka.sisko@um.si 
in $70 \%$ ethanol for $2 \mathrm{~min}$ and then $2 \mathrm{~min}$ immersion, with agitation, in $4.6 \% \mathrm{NaOCl}$ containing two drops of Tween 20 (T1); (b) the explants were dipped in $70 \%$ ethanol for $2 \mathrm{~min}$ and then $10 \mathrm{~min}$ immersion, with agitation, in $4.6 \% \mathrm{NaOCl}$ containing two drops of Tween 20 (T2); (c) the explants were dipped in $70 \%$ ethanol for $2 \mathrm{~min}$ and then in solution of 16 $\%$ dichloroisocyanuric acid in combination with $8 \%$ silver nitrate for $2 \mathrm{~min}$, with agitation, containing two drops of Tween 20 (T3); (d) the explants were dipped in 70\% ethanol for $2 \mathrm{~min}$ and then in solution of $16 \%$ dichloroisocyanuric acid in combination with $8 \%$ silver nitrate for $10 \mathrm{~min}$, with agitation, containing two drops of Tween 20 (T4). After the application of all four sterilisation methods, the explants were rinsed into sterilised distilled water (3 times) in order to remove all traces of the sterilising substances. All manipulation of plant material was done under aseptic condition.

After sterilisation, the explants were cultured on induction media (Table 1) in petri dishes. Plants were incubated in growth chamber at $21{ }^{\circ} \mathrm{C}$ with a 15 hours photoperiod (15.000 Lux) and investigated for contamination every 3 to 4 days after incubation. Explants receiving different treatments were incubated for one month. For each treatment, the contamination rate $(\mathrm{Cb})$ was calculated as a percentage of contaminated explants, survival rate $(\mathrm{Sb})$ as a percentage of non-contaminated and vital explants, and deceased rate (Db) as a percentage of non-vital explants.

The experiment included 4 treatments in four replicates, with each replicate consisting of 5 explants for 3 different genotypes. The obtained results were subjected to analysis of variance (ANOVA) using Statgraphics Centurion XV (2005) to ascertain significant differences between treatments $(P<$ 0.05). In order to improve the normality of distribution all the data were arcsin-transformed. Differences between means were revealed by Duncan's multiple range test $(\alpha=0.05)$.

\section{Proliferation}

One month after induction, all vital and not contaminated explants were transferred on five propagation media (P1, P2, P3, P4, and P5), based on two different basal media (MS and McCown woody plant medium) supplemented with different plant growth regulators (Table 1). On media P1, P2, P3, and P4, 24 explants were cultured on each media in jars. Each jar contained one explant. After five weeks, there were no new shoots developed on four media used in the experiment. Because of bad regeneration on these media, all obtained explants (95) were transferred on the medium P5. After five weeks, the number of shoots per explant was recorded, and multiplication rate was calculated for each media.

\section{Rooting in vitro}

This experiment was carried out to study the effect of two different plant growth regulators on root formation. Two media were prepared (Table 1) one with $0.5 \mathrm{mg} / \mathrm{L}$ IBA and the other with $0.5 \mathrm{mg} / \mathrm{L}$ NAA. Shoots of the three studied genotypes, in length from $1.5 \mathrm{~cm}$ to $3 \mathrm{~cm}$, were placed on each medium: 13 shoots of the garden $H$. macrophylla genotype 1,8 shoots of potted $H$. macrophylla genotype 2, and 15 shoots of potted $H$.

Table 1: Composition of the media used for micropropagation of $H$. macrophylla.

\begin{tabular}{|c|c|c|c|c|c|c|c|c|}
\hline \multirow{2}{*}{ Component } & \multirow{2}{*}{$\begin{array}{l}\text { Induction } \\
\text { medium }\end{array}$} & \multicolumn{5}{|c|}{ Propagation media } & \multicolumn{2}{|c|}{ Rooting media } \\
\hline & & P1 & P2 & P3 & $\mathrm{P} 4$ & P5 & $\mathrm{R} 1$ & $\mathrm{R} 2$ \\
\hline MS including vitamins $(\mathrm{g} / \mathrm{L})$ & 4.3 & 4.3 & 4.3 & 4.3 & 4.3 & - & - & - \\
\hline McCown woody plant medium & - & - & - & - & - & 2.46 & 2.46 & 2.46 \\
\hline Sucrose $(\mathrm{g} / \mathrm{L})$ & 30.0 & 30.0 & 30.0 & 30.0 & 30.0 & 20.0 & 20.0 & 20.0 \\
\hline 6-benzylaminopurine (BAP) (mg/L) & - & 5 & 2 & 5 & 4 & 2 & - & - \\
\hline $2 \mathrm{iP}(\mathrm{mg} / \mathrm{L})$ & - & 2 & 2 & 2 & - & - & - & - \\
\hline Naphthoxyacetic acid(NOA) (mg/L) & - & - & - & 0.1 & - & - & - & - \\
\hline Indole-3-butyric acid (IBA) (mg/L) & - & - & - & - & - & - & 0.5 & - \\
\hline Naphthalene acetic acid (NAA) (mg/L) & - & - & - & - & - & 0.005 & - & 0.5 \\
\hline L-prolin (mg/L) & 200.0 & 200.0 & 200.0 & 200.0 & 200.0 & - & - & - \\
\hline Myo-inositol (mg/L) & 400.0 & 100.0 & 100.0 & 100.0 & 100.0 & 100.0 & 100.0 & 100.0 \\
\hline Nicotinic acid (mg/L) & - & - & - & - & - & 1.0 & 1.0 & 1.0 \\
\hline Tiamin $(\mathrm{mg} / \mathrm{L})$ & - & - & - & - & - & 2.0 & 2.0 & 2.0 \\
\hline Pyridoxine hydrochloride (mg/L) & - & - & - & - & - & 1.0 & 1.0 & 1.0 \\
\hline $\operatorname{Agar}(g / L)$ & 8.0 & 8.0 & 8.0 & 8.0 & 8.0 & 8.0 & 8.0 & 8.0 \\
\hline $\mathrm{pH}$ & 5.8 & 5.8 & 5.8 & 5.8 & 5.8 & 5.8 & 5.8 & 5.8 \\
\hline
\end{tabular}


macrophylla genotype 3. The number of rooted plants was counted every 14 days.

\section{RESULTS AND DISCCUSSION}

\section{Effect of disinfection treatments on successful sterilisation and survival rate of explants}

The difference among different disinfection treatment was established. The T3 and T4 (both included dichloroisocyanuric acid in combination with silver nitrate) gave significantly higher survival rate $(63.33 \%$ and 55.00 , \% respectively) comparing to $\mathrm{T} 1$ and $\mathrm{T} 2$ (based on $\mathrm{NaOCl}$ ) with lower survival rate $(10.00 \%$ and $26.67 \%$, respectively).

The data presented in Table 2 indicate that there were no significant differences among different disinfection treatments in the genotype 1. For genotype 2, the treatment 3 resulted in significantly higher mean percentages of contamination-free explants $(90.00 \%)$. In genotype 3 there were also significant differences among different treatment methods. The highest survival rate was obtained with T3, T4, and T2 (80.00\%,
$75.00 \%$ and $55.00 \%$, respectively).

In Table 3, the impacts of genotype and disinfection method on the survival rate are shown. Interaction between genotype and disinfection treatment was not statistically significant. The differences in survival rate among three genotypes were statistically significant at $P<0.001$. The genotypes 2 and 3 had higher survival rate comparing to the genotype 1 of which the highest percentage of contamination rate was obtained (58.75 $\%)$. Those results were expected, due to the reason that G1 was growing outside, in a garden, where plants could be more contaminated comparing to potted plants (G2, G3) which were grown under controlled condition in a greenhouse. If an explant is isolated from a plant grown outside, there is a much higher chance of infection taking place (Pierik 1997).

\section{The influence of medium composition on proliferation}

Vital explants of three different genotypes were transferred on five different shoot proliferation media (Table 1). Media P1-P4 included MS (Murashige and Skoog 1962) as basal

Table 2: The effects of four different disinfection methods (T1, T2, T3, and T4) for three H. macrophylla genotypes (G1, G2, and G3) on the survival, contamination, and deceasing rate of explants.

\begin{tabular}{|c|c|c|c|c|c|c|c|c|c|}
\hline & \multicolumn{3}{|c|}{ Survival rate (\%) } & \multicolumn{3}{|c|}{ Contamination rate $(\%)$} & \multicolumn{3}{|c|}{ Deceasing rate (\%) } \\
\hline & $\mathrm{G} 1^{\mathrm{ns}}$ & $\mathrm{G} 2^{*}$ & $\mathrm{G}^{*}$ & $\mathrm{G} 1^{\star *}$ & $\mathrm{G} 2^{*}$ & $\mathrm{G}^{*}$ & $\mathrm{G} 1^{\mathrm{ns}}$ & $\mathrm{G} 2^{\text {ns }}$ & $\mathrm{G} 3^{\text {ns }}$ \\
\hline $\mathrm{T} 1$ & 5.0 & $15.0 \mathrm{~b}$ & $10.0 \mathrm{~b}$ & $90.0 \mathrm{a}$ & $70.0 \mathrm{a}$ & $70.0 \mathrm{a}$ & 5.0 & 15.0 & 20.0 \\
\hline $\mathrm{T} 2$ & 0.0 & $25.0 \mathrm{~b}$ & $55.0 \mathrm{ab}$ & $90.0 \mathrm{a}$ & $60.0 \mathrm{a}$ & $35.0 \mathrm{ab}$ & 10.0 & 15.0 & 10.0 \\
\hline T3 & 20.0 & $90.0 \mathrm{a}$ & $80.0 \mathrm{a}$ & $35.0 \mathrm{~b}$ & $5.0 \mathrm{~b}$ & $15.0 \mathrm{~b}$ & 45.0 & 5.0 & 5.0 \\
\hline $\mathrm{T} 4$ & 40.0 & $50.0 \mathrm{ab}$ & $75.0 \mathrm{a}$ & $20.0 \mathrm{~b}$ & $50.0 \mathrm{a}$ & $20.0 \mathrm{~b}$ & 40.0 & 0.0 & 5.0 \\
\hline
\end{tabular}

***,**, ${ }^{*}$ Significant at $P<0.001, P<0.01, P<0.05$, respectively; ns $=$ not significant.

Table 3: The effects of hydrangea genotype $(G)$ and disinfection treatment $(T)$ on the buds survival rate $(\mathrm{Sb})$, contamination rate $(\mathrm{Cb})$, and rate of deceased buds $(\mathrm{Db})$.

\begin{tabular}{|c|c|c|c|}
\hline Source of variation & $\begin{array}{c}\mathrm{Sb} \\
(\arcsin )\end{array}$ & $\begin{array}{c}\mathrm{Cb} \\
(\arcsin )\end{array}$ & $\begin{array}{c}\mathrm{Db} \\
(\arcsin )\end{array}$ \\
\hline Genotype (G) & $* * *$ & * & ns \\
\hline Disinfection treatment $(\mathrm{T})$ & $* * *$ & $* * *$ & ns \\
\hline $\mathrm{G} \times \mathrm{T}$ & ns & ns & ns \\
\hline & \multicolumn{3}{|c|}{ Mean \pm SEM } \\
\hline $\begin{array}{l}\text { G1 } \\
\text { G2 } \\
\text { G3 } \\
\end{array}$ & $\begin{array}{c}16.25 \pm 8.21 \mathrm{~b} \\
45.00 \pm 12.04 \mathrm{a} \\
55.00 \pm 11.90 \mathrm{a} \\
\end{array}$ & $\begin{array}{c}58.75 \pm 11.18 \mathrm{a} \\
46.25 \pm 11.93 \mathrm{ab} \\
35.00 \pm 10.57 \mathrm{~b}\end{array}$ & $\begin{array}{c}25.00 \pm 8.66 \\
8.75 \pm 4.46 \\
10.00 \pm 4.47 \\
\end{array}$ \\
\hline Disinfection treatment & $\begin{array}{c}10.00 \pm 5.77 b \\
26.67 \pm 12.87 \mathrm{~b} \\
63.33 \pm 12.99 \mathrm{a} \\
55.00 \pm 14.38 \mathrm{a}\end{array}$ & $\begin{array}{c}76.67 \pm 10.96 \mathrm{a} \\
61.67 \pm 12.18 \mathrm{a} \\
18.33 \pm 9.36 \mathrm{~b} \\
30.00 \pm 12.91 \mathrm{~b}\end{array}$ & $\begin{array}{l}13.33 \pm 5.69 \\
11.67 \pm 6.26 \\
18.33 \pm 9.03 \\
15.00 \pm 8.57\end{array}$ \\
\hline
\end{tabular}

***, ${ }^{* *},{ }^{*}$ Significant at $P<0.001, P<0.01, P<0.05$, respectively; ns $=$ not significant.

${ }^{\mathrm{a}-\mathrm{b}}$ Means $( \pm$ SEM) followed by different letters within particular factor are significantly different (Duncan, $\alpha=0.05$ ) 
medium, medium P5 was based on McCown woody plant medium (Lloyd and McCown 1980). On media with MS, no multiplication was obtained. On P5 medium, 126 shoots were obtained from 95 explants after 5 weeks, which gave multiplication rate of 1.31 . For the media P1, P2, P3, and $\mathrm{P} 4$, the multiplication rate was 1.0. Among the three studied genotypes, no significant differences in multiplication rate were observed.

Table 4: Multiplication rate for $H$. macrophylla on five different media $(n=24)$.

\begin{tabular}{|l|c|c|c|}
\hline Medium & $\begin{array}{c}\text { Number of } \\
\text { explants }\end{array}$ & $\begin{array}{c}\text { Number of } \\
\text { shoots after } \\
5 \text { weeks }\end{array}$ & $\begin{array}{c}\text { Multiplication } \\
\text { factor }\end{array}$ \\
\hline P1 & 24 & 24 & 1 \\
\hline P2 & 24 & 24 & 1 \\
\hline P3 & 24 & 24 & 1 \\
\hline P4 & 23 & 23 & 1 \\
\hline P5 & 95 & 126 & 1.33 \\
\hline
\end{tabular}

\section{Effect of different media on rooting}

Shoots in size of 1.5 to $3 \mathrm{~cm}$ were placed on two rooting media with McCown woody plant medium supplemented with IBA at $0.5 \mathrm{mg} / \mathrm{L}$ (R1) and McCown woody plant medium supplemented with NAA at $0.5 \mathrm{mg} / \mathrm{L}$ (R2) (Table $1)$. In the case of genotype 1 , more shoots developed roots on the medium R2 (62.5\%) comparing to the medium R1 (50.00 $\%)$. The best genotype for rooting was genotype 2 , where the percentage of rooted plants was the highest on R1 medium $(100.00 \%)$. In genotype $3,66.67 \%$ of rooted shoots were obtained on medium R1.

\section{CONCLUSIONS}

In the present study the method to initiate in vitro culture of potted and garden $H$. macrophylla and its multiplication and in vitro rooting was studied. The presented results indicate that the effective in vitro regeneration of $H$. macrophylla was established. Based on the results shown above, it is possible to conclude that there was a significant impact of the studied genotypes on successfully obtained sterile culture of $H$. macrophylla. When using potted plants, the number of successfully disinfected explants was much higher (up to $55 \%$ ) comparing to those grown in a garden (with $16.25 \%$ disinfected and survived explants). Disinfection treatments with dichloroisocyanuric acid in combination with silver nitrate gave a significantly higher survival rate comparing to treatments based on $\mathrm{NaOCl}$. The successful shoot multiplication was achieved on McCown woody plant medium, supplemented with BAP at $2 \mathrm{mg} / \mathrm{L}$ and NAA at $0.005 \mathrm{mg} / \mathrm{L}$. The best rooting was obtained with genotype 2 on McCown woody plant medium, supplemented with 0.5 $\mathrm{mg} / \mathrm{L} \mathrm{IBA}$ (100.00\% of rooted plants).

\section{ACKNOWLEDGMENTS}

I would like to express my gratitude to Nina Žnidarič for assistance with the experiments.

\section{REFERENCES}

1. Abou Dahab TAM. In vitro propagation of Hydrangea macrophylla Thunb. Arab J. Biotech. 2007; 10(1):161-178.

2. Harrison L. Latin for gardeners. United Kingdom, Mitchell Beazley. 2012;p.224.

3. Lloyd GB, McCown BH. Commercially-feasible micropropagation of mountain-laurel, Kalmia latifolia, by use of shoot tip culture. Comb. Proc. Int. Plant Prop. Soc.1980; 30: 412-427.

4. Murashige T, Skoog F. A revised medium for rapid growth and bio assays with tobacco tissue cultures. Physiol. Plant. 1962; 15:473-497.

5. Pierik RLM. In vitro culture of higher plants. The Netherlands, Kluwer academic publishers. 1997;p.87.

6. Ruffoni B, Sacco E, Savona M. In vitro propagation of $\mathrm{Hy}$ drangea spp.. Methods Mol. Biol. 2013; 11013:231-244.

7. Sebastian TK, Heuser CW. In vitro propagation of Hydrangea quercifolia Bartr. Scientia Hort. 1987; 31:303-309. 


\section{Iniciacija rastlinske tkivne kulture lončne in vrtne hortenzije (Hydrangea macrophylla) $\mathrm{v}$ in vitro razmerah}

\section{IZVLEČEK}

Proučevali smo vpliv različnih načinov sterilizacije na uspešno vzpostavitev tkivne kulture treh genotipov hortenzije (Hydrangea macrophylla). Ugotovili smo, da obstajajo razlike med različnimi načini sterilizacije. Sterilizacija $\mathrm{z}$ dikloroizocianurno kislino $\mathrm{v}$ kombinaciji s srebrovim nitratom je bila uspešnejša od sterilizacije $\mathrm{z}$ uporabo $\mathrm{NaOCl}$. Na uspešnost sterilizacije je vplival tudi genotip. Lončne hortenzije (genotipa G2 in G3) so kazale večjo sposobnost sterilizacije (pri genotipu G2 smo tako dobili $45.00 \%$, pri G3 pa $55.00 \%$ uspešno steriliziranih poganjkov) v primerjavi z vrtno hortenzijo, kjer je bilo največ okuženih poganjkov (58.75 \%). Za namnoževanje poganjkov se je kot najboljše izkazalo gojišče McCown z dodatkom $2 \mathrm{mg} / \mathrm{L}$ BAP in $0.005 \mathrm{NAA}$, na katerem je bil faktor namnoževanja 1,31 v petih tednih. Najbolje je koreninil genotip 2 na McCown osnovnem gojišču z dodano 0,5 mg/L IBA in sicer je na tem gojišču koreninilo $100 \%$ poganjkov.

Ključne besede: mikropropagacija, tkivna kultura, hortenzija, Hydrangea macrophylla, sterilizacija rastlin 